some solar or geophysical event of special interest. A similar scheme is being used in the IQSY with some special features appropriate to the solar minimum period. An IQSY geophysical calendar has been issued and the alerts will give warning not only of impending storm conditions but also of solar and magnetic calm.

The International Committee responsible for planning and organizing the IQSY is a special committee established by the International Council of Scientific Unions, and it is supported financially by that Council, by Unesco and by contributions from participating nations. It consists of representatives of the four scientific unions which are directly concerned with the IQSY together with representatives of other interested international scientific bodies such as the World Meteorological Organization, the Committee for Antarctic Research and the International Committee for Space Research (COSPAR). The Space Research Committee has no fewer than four representatives on the IQSY Committee-this being an indication of the importance which we have chosen to place on space research in the programme. The IQSY Secretariat has been set up in London-in accommodation kindly provided by the Royal Society.

One of the difficult features of establishing an international scientific committee is that the actual elected membership of the committee is often distributed very unevenly over the globe. In setting up the IQSY Commit- tee we have tried to meet this problem to some degree by having four additional members elected on a regional basis.

An international project of this sort depends for its success on the goodwill of scientific academies, of national governments and their research institutions, and above all it depends on the willing co-operation of many individual scientific workers scattered throughout the world. The IQSY Committee has received warm co-operaition on all sides, and it is good to report that no fewer than 70 nations are actively participating, including all those which co-operated in the IGY.

The IQSY is the fourth international co-operative effort in geophysics since 1882 and the second world-wide effort within a period of seven years. When the enterprise ends next year a vast store of geophysical results covering periods of both maximum and minimum solar activity will have been assembled and made readily available for further extended study. We may hope that some time in the future these data will yield the answers to some of the outstanding problems of the Sun and the Farth and thus, to quote again Sir Arthur Rücker at the British Association meeting of 1898, "crown the efforts not merely of those on whom the first glimpse of the truth may flash, but also the international co-operation which has, by way of preparation, made 'the crooked straight and the rough places plain'."

\title{
OBITUARIES
}

\section{Dr. K. H. Barnard}

Dr. K. H. Barnard died on September 22 at the age of seventy-seven, after fifty-three years working at the South African Museum in Cape Town. He was the director from 1946 until his retirement in 1956. With his death South Africa has lost one of her greatest zoologists.

Dr. Barnard was born in London on March 31 , 1887, educated at a private school in England and at the Realgymnasium in Mannheim, Germany, where he went in order to learn German to help him with his studies. $\mathrm{He}$ went on to Christ's College, Cambridge, in 1905, where he took the Natural Science Tripos in botany, geology and zoology, and obtained his B.A. three years later. He also attended the new and then rather unusual courses on anthropology, ethnology and geography. After that he proceeded to study law, and was called to the Bar (Middle Temple) in 1911. He obtained his M.A. (Cantab.) in absentia in 1913. Science interested him more than law, however, and he returned to zoology. A.fter a short time as honorary naturalist at the Marine Biological Laboratory in Plymouth he joined the staff of the South African Museum in 1911, where he continued to work until his death. He obtained the degree of D.Sc. from the University of Cape Town in 1924 for his work on the distribution of Crustacea, and in 1956 the University of Stellenbosch conferred on him the degree of D.Sc. honoris causa. During his life he produced more than two hundred articles, scientific papers and books.

At the South African Museum he took charge of the Marine collections, including the large collection amassed by the Cape Government trawler S.S. Pieter Faure. Based largely on an investigation of the collections in the South African Museum, he published many taxonomic works, including a series of papers on amphipods and isopods (1914-25), a monograph of South African marine fishcs (1925-27), a monograph of South A.frican crabs, prawns and mantis-shrimps (1950), and contributions to the South African marine mollusca (1958-64). He also made investigations of the Amphipoda from expeditions such as the Discovery and the Terra Nova. the Great Barrier
Reef, the John Murray, the Investigator and the Aus. tralasian Antarctic, and contributed important papers in their reports. He also published reports for the British Museum, the Indian Museum, Transvaal Museum, Natal Museum and Durban Museum. His work has greatly increased our knowledge of the fauna of the seas around South Africa and farther afield. He published three popular books on fishes (1947), shells (1951) and shore life (1954).

His keen interest in mountaineering and the discovery of Phreatoicus, an Australasian genus of primitive Crustacea on Table Mountain, led to an intensive investigation of the mountain fauna of the south-west Cape ranges. Evidence of a relict fauna was investigated and studied in relation to the geology and topography. His presidential address to the South African Geographical Society in 1936 summarized some of the more important results of these investigations and the conclusions drawn from them concerning the former topography of the mountain ranges and the river courses. This work involved numerous collecting trips in the mountains of the South-west Cape. $\mathrm{He}$ made extensive collecting expeditions to the coast of Portuguese East Africa in 1912 , the Natal coast in 1913 , the Natal interior in 1917 , Ovamboland and the Kaokoveld and north to the Kunene River in 1921, 1923 and 1926 (Zoological Survey of South West Africa) and Gordonia and the Orange River to the Aughrabies Falls in 1925. Some of these early trips were made by ox-wagon. He published many important papers on the fauna of the mountains and rivers of South Africa, based largely on his own collections.

He served as local secretary for the compilation of the international catalogue of scientific literature until the London secretariat took over the whole compilation, including records of papers published in South Africa. $\mathrm{He}$ helped in the formation of the South African Geographical Society in 1917, served on the Council for several years, was president for the session $1935-36$ and the Society's representative at the International Geographical Congress at Cambridge in 1928. After his retirement he concentrated his research work on South African marine mollusca, his research work and publications being aided 
by a senior bursary from the South African Council for Scientific and Industrial Research.

Dr. Barnard was awarded many honours during his life-time, including being elected a Fellow of the Royal Society of South Africa in 1920, and a Fellow of the Linnean Society of London in 1921. He received the Gold Badge of the Mountain Club of South Africa in 1924, the King George V Silver Jubilee Medal in 1935, the Senior Captain Scott Medal of the South African Biological Society in 1936, the Medal and grant of the South African Association for the Advancement of Science in 1945, the Queen Elizabeth II Coronation Medal in 1953. He was made an Honorary Fellow of the Royal Society of South Africa in 1956 and president of the Conchological Society of Southern Africa in 1962.

Dr. Barnard was recognized as a world authority in several fields, and it was often with astonishment that specialists in one of these subjects would discover his accomplishments in other fields. Dr. Barnard's worldwide reputation was built up on his unceasing and prodigious work over a long and active life. He was always willing to help his scientific colleagues or casual enquirers in his quiet, unassuming way. Despite his achievements, he remained a shy and modest man.

Our sympathy is extended to his wife and two children who survive him. John R. GRINDLEY

\section{Prof. F. H. Garner, O.B.E.}

Frederic H. Garner, emeritus professor of chemical engineering in the University of Birmingham, died suddenly at the age of seventy-one at his home at Wymeswold, Leicestershire, on September 19. Born in 1893, he attended the Market Bosworth Grammar School, going on to study chemistry at the University of Birmingham, and then proceeding to the Mellon Institute, Pittsburgh, for postgraduate studies.

After his return to England he was actively associated with the petroleum industry for many years, rising to become director of research of the Esso European Labor. atories from 1935 until 1942.
He will be remembered particularly, however, for the enthusiasm he brought to bear in building up the Department of Chemical Engineering in the University of Birmingham. When in 1942 he was appointed to succeed A. W. Nash as professor and head of the Oil Mining Department, the latter was small and rather static; the undergraduate intake was only five students that year. and even fewer men were able to come as the Second World War progressed.

In 1946 Garner changed the name to the Department of Chemical Engineering, and began the programme of diversification and expansion that, in a little over a decade, transformed a small Department of Oil Mining into one of the largest Chemical Engineering Departments in the world. The academic staff increased from 3 to 28 and undergraduate admissions from 3 or 4 a year to about 80 ; postgraduate lecture courses were established both in chemical engineering and also (with remarkable foresight) in biological chemical engineering. The research school, too, increased in size and prestige, to an intake of about 23 new students each year. It was inevitable that the Department that he built up with such enthusiasm should become a dominant factor in his life. Inevitable also, perhaps, was Garner's role as the watchful, sometimes strict, father to his staff.

In his own research, he was particularly interested in later years in the surface phenomena associated with mass-transfer, and he was one of the pioneers in investigations of the circulation within falling drops and in the visualization of interfacial turbulence. Even after his retirement in 1960 he used to come into the Department to continue his experiments in these fields.

His death marks the end of an era-an era not only of the establishment of chemical engineering in British universities, but also of the benevolent-dictator type of professor who could, by his endeavours and by the impact of his personality, build up a large Department as his personal creation. Until the moment of his retirement it was his department in a very real sense, and he will long be remembered for his devotion to its interests and to those of his many students.
J. T. DAvies

\section{NEWS and VIEWS}

The Royal Society of Edinburgh: Elections to Council

At the annual statutory meeting of the Royal Society of Edinburgh, held on October 26, the following were elected to the Council of the Society for the 182nd session: President, Prof. J. N. Davidson; Vice-Presidents, Dr. H. R. Fletcher, Prof. G. L. Montgomery, Prof. C. F. Davidson, Dr. Mowbray Ritchie, Prof. J. Allen and Dr. G. H. Mitchell; General Secretary, Prof. N. Feather; Secretaries to Ordinary Meetings, Prof. A. E. Ritchie and Dr. A. F. Brown; Treasurer, Dr. J. R. Peddie; Curator of Library and Museum, Dr. R. Schlapp; Councillors, Prof. R. B. Fisher, The Rev. A. M. Gillespie, Prof. A. Robertson, Prof. P. A. Sweet, The Rt. Hon. Lord Balerno of Currie, Dr. J. M. Jackson, Prof. I. N. Sneddon, Prof. P. E. Weatherley, Dr. N. Campbell, Prof. P. L. Pauson, Prof. J. R. Raeburn and Prof. J. D. Robertson.

\section{Director of Smithsonian's Museum of History and Technology: Mr. John C. Ewers}

Mr. JoHn C. Ewers has been appointed director of the new Smithsonian Museum of Fistory and Technology in succession to Mr. Frank A. Taylor, who has been serving as both acting director of the Museum and director of the U.S. National Museum. Mr. Taylor will continue in the latter post. A native of Cleveland, Ohio, Mr. Ewers began his service with the Smithsonian Institution in 1946. For the past six years he has been assistant director of the Museum of History and Technology, serving as planning officer for the new building. He was responsible for the design, construction, and installation of exhibits, which made it possible to open the building to the public in January 1964, a few months after its completion. Before joining the Smithsonian Institution, Mr. Ewers was a. member of the Bureau of Indian Affairs, serving as the first curator of the Museum of the Plains Indian at Browning, Montana. He also has acted as museum planning consultant to the Historical Society of Montana, the Bureau of Indian Affairs, and the National Park Service. Recently he was consultant for the Canadian National Museum in planning its new museum of history and anthropology. A graduate of both Dartmouth College and Yale University, Mr. Ewers is a member of several professional societies, including the Washington Academy of Sciences, American Association of Museums, American Anthropological Association, Sigma $X i$, Western History Association, and the American Indian Ethnohistoric Conference. $\mathrm{He}$ is also past-president of the Westerners, a Washington group interested in the history of the American West.

\section{Environmental Design and Engineering at University College, London: Prof. R. G. Hopkinson}

DR. R. G. Hopkinson has been appointed to the new chair of environmental design and engineering in the Bartlett School of Architecture, at University College, London. The establishment of this chair has been made 